\title{
Development of Anti-bodies against Infliximab in Iraqi Patients with Rheumatoid Arthritis.
}

\author{
Mohammed A.Al-Karkhi* \\ MuhammedM.Al-Ani* \\ NizarA.Jassim** \\ BatoolM.Mahdi*** \\ Layth abd-alailah****
}

\author{
MBChB, MSc, PhD \\ MBChB, MSc, FICMS \\ FICMS \\ MBChB, MSc, FICMS \\ MBChB,FICMS
}

\begin{abstract}
Background: Rheumatoid arthritis is a common chronic and destructive autoimmune arthropathy . Treatment with infliximab gives great improvement to a large numbers of patients with RA, however, in some patients after prolonged treatment infliximab can induce anti-infliximab antibodies formation and result to loss of infliximab efficacy and active persistent disease.

Fac Med Baghdad

2015; Vol.57, No.3

Received:May, 2015

Accepted:June, 2015

Objective: to investigate the frequency of anti-infliximab antibodies in Iraqi patients with rheumatoid arthritis.

Patients and methods: fifty Iraqi RA patients(36 females and 14 males) compared with 50 control( 25 healthy control and 25 case control (patients with RA on other treatment) ) were included in this study from begging of March 2014 till end of September 2014.All patients were diagnosed by full history, complete clinical examination and laboratory test. Anti-infliximab antibodies were meatured using enzymelinked immunosorbent assay in serum of Iraqi patients with RA treated with infliximab more than 3 months duration.

Results: Antibodies to infliximab were detected in 35(70\%) Iraqi RA patients, while the patients without detectable antibodies against infliximab were $15(30 \%)$,also there were no anti-infliximab antibodies in the control groups.

Conclusion: In this study, nearly three quarter of the Iraqi RA patients treated with infliximab developed anti-infliximab antibodies.

Key words: rheumatoid arthritis, infliximab, anti-infliximab antibodies.
\end{abstract}

\section{Introduction:}

Rheumatoid arthritis (RA) is a common systemic autoimmune disease can affect any tissues and organs but it mainly cause a chronic synovial inflammation of joints(1). Although the cause of RA still unknown, genetic and environmental factors play an important role in its pathogenic mechanisms(2). Because the inflammatory cytokines mainly interleukin-1(IL1), interleukin-6(IL-6) and tumor necrosis factor- $\alpha$ (TNF- $\alpha$ ) are elevated in synovial fluid and blood of patients with RA, so considered to be an association between these cytokines and pathogenesis of RA(3)

Treatment of RA with biological agents mainly infliximab showed a great improvement in daily activities of patients with RA, this agent acts as TNF- $\alpha$ blocker(4).

Infliximab which is known as chimeric monoclonal antibody because it composed of constant region of human IgG1 and

*-Corresponding Auther:Dept.ofMicrobiology\&Immunology,college of medicine, University of Baghdad.misk62@yahoo.com

**Reumatology Unit, Deparment of Medicine, College of Medicine, University of Baghdad.

***Dept. of Microbiology \&Immunology,Al-Kindy Medical college.

****Histocompatibility Lab . Organ transplant center , Al-Karama Hospital. variable region of murine part target TNF- $\alpha$,specifically binding with TNF- $\alpha$ result in the following outcome; neutralization of soluble TNF- $\alpha$ physiological effects; dissociation of TNF- $\alpha$ from complex with its receptor; and acts on cells produce TNF- $\alpha$ by the mechanisms include; antibody-dependent cell cytotoxicity(ADCC) , complement-dependent cytotoxicity (CDC) and apoptosis of these cells (5-7). The infliximab is effective in the treatment of many autoimmune diseases such as RA (8), Ankylosing spondylitis (9), Psoriasis (10), Cronh's disease(11) and Wegener's garanulomatosis(12). Although,many patients with RA had a great initial effectiveness of infliximab treatment, others not respond to this biological agents several months after treatment(13).

In our study we investigated the development of anti-infliximab antibodies in patients with RA who had been received this biological treatment and then recorded the relationship between the effectiveness of this agent and emergence of these antibodies.

\section{Patients and methods:}

Fifty patients (36 females and 14 males), their mean age(45.3) years who attended to medical city, Baghdad teaching hospital, 
Department of Rheumatology(Biological therapy unit) included in this study during period From begging of March 2014 till end of September 2014, all patients were treated with biological agent (intravenous infusion of Infliximab of $3 \mathrm{mg} /$ $\mathrm{kg}$ at baseline, and at 2 and 6 weeks then every 8 weeks), for least three months duration, all subset agreed to participated in research.

The patients were compared to 50 control group ( 25 patients with RA on other treatment and 25 healthy individuals from central blood bank ) who were randomly selected as a control groups .

All these patients met the revised criteria for RA (the American College of Rheumatology 1987) (14) and their disease activity was assessed by using Disease Activity Score in 28 joints $(15,16)$

Samples of serum were collected from each patient with RA receive infliximab infusion for at least 3 months duration for assessment of anti-infliximab antibodies. Anti-infliximab antibodies were detected by enzyme-linked immunosorbent assay using Antibody to Infliximab ELISA kit (Matriks Biotek, Germany).

\section{Results:}

Fifty patients with RA (36 females and 14 males) their mean age was (45.24 \pm 9.15$)$ years, and 50 control group(25 healthy and 25 case control),32 females and 18 males, their mean age was $(42.22 \pm 8.23)$ years were included in this study as shown in table 1.
Table 1:Demographic characteristic of the case study and control.

\begin{tabular}{ccccccc}
\hline \multirow{2}{*}{ Gender } & \multicolumn{2}{c}{$\begin{array}{c}\text { Patients } \\
\text { with R.A } \\
\text { No. }\end{array}$} & Mean age & & \multicolumn{2}{c}{ Controls } \\
No. & $\%$ & Mean age \\
& 14 & 28.0 & $41.57 \pm 7.51$ & 18 & 36 & $40.56 \pm 6.53$ \\
\hline Male & 14 & & & \\
\hline Female & 36 & 72.0 & $46.66 \pm 9.16$ & 32 & 64 & $43.34 \pm 8.13$ \\
\hline Total & 50 & 100.0 & $45.24 \pm 9.15$ & 50 & 100 & $42.22 \pm 8.23$ \\
\hline
\end{tabular}

Student t-test $=1.72, \mathrm{P}=0.088$

The anti-infliximab anti-bodies were detected in $35(70.0 \%)$ patients(23(65.7\%)were females and 13(34.3\%) were males), and not detected in 15(30.0\%)patients,(13(86.7\%)were females and $2(13.3 \%)$ were males)with sensitivity (70\%) and specificity (100\%), while no antibodies were detected in control group as shown in table 2 and 3.

Table 2: Distribution of serum anti-infliximab antibodies of the case study and controls.

\begin{tabular}{ccccc}
\hline Anti-infliximab Ab & *Patients N0.\% & $* *$ Control No. $\%$ \\
\hline+ ve & 35 & 70.0 & 0 & 0.0 \\
\hline -ve & 15 & 30.0 & 50 & 100.0 \\
\hline Total & 50 & 100.0 & 50 & 100.0 \\
\hline
\end{tabular}

$\mathrm{X} 2=50.81, \mathrm{P}=0.000001 *$ patients with R.A

$* *$ control (case and healthy control)

Sensitivity: 70\% [55; 82] (95\% confidence interval)

Specificity: $100 \%[91 ; 100]$ (95\% confidence interval).

Table 3:Distribution of anti-infliximab antibodies according to gender.

\begin{tabular}{cccccccc}
\hline \multirow{2}{*}{ Anti-infliximab ab } & \multicolumn{9}{c}{ Gender } & \multicolumn{2}{c}{ Total } \\
\cline { 2 - 8 } & Male & $\%$ & Female & $\%$ & Number & \% \\
\hline tve & 12 & 85.7 & 23 & 63.9 & 35 & $\mathbf{3 0}$ & $\mathbf{3 0 . 0}$ \\
\hline -ve & 2 & 14.3 & 13 & 36.1 & 50 & 100.0 \\
\hline Total & 14 & 100.0 & 36 & 100.0 &
\end{tabular}

$\mathrm{X} 2=1.37, \mathrm{P}=0.242$

In table 4 , the anti-infliximab anti-bodies were reported in patients age groups,10(66.7\%)in patients with age $(<=40)$, $16(76.2 \%)$ patients in between(41-50) years, and 9(64.3\%) in patients age groups $(>50 \%)$. On the other hand, these anti-bodies were negative in same age groups as follow (5(33.3\%) in $(<=40), 5(23.8 \%)$ in $(41-50)$ and 5(35.7) in (>50)respectively, show that no statistical difference between positive and negative anti-bodies in these patients age groups.
Table ${ }^{\text {: }}$ Distribution of anti-infliximab antibodies according to age group. Crosstab

\begin{tabular}{|c|c|c|c|c|c|}
\hline & & & \multicolumn{2}{|c|}{$\begin{array}{c}\text { Anti } \\
\text { inifliximab }\end{array}$} & \multirow[t]{2}{*}{ Total } \\
\hline & & & $+v e$ & -ve & \\
\hline \multirow{6}{*}{ AgeGp } & \multirow{2}{*}{$<=40$} & Count & 10 & 5 & 15 \\
\hline & & $\%$ within AgeGp & $66.7 \%$ & $33.3 \%$ & $100.0 \%$ \\
\hline & \multirow{2}{*}{$41-50$} & Count & 16 & 5 & 21 \\
\hline & & \% within AgeGp & $76.2 \%$ & $23.8 \%$ & $100.0 \%$ \\
\hline & \multirow{2}{*}{$>\mathbf{5 0}$} & Count & 9 & 5 & 14 \\
\hline & & \% within AgeGp & $64.3 \%$ & $35.7 \%$ & $100.0 \%$ \\
\hline \multirow[t]{2}{*}{ Total } & & Count & 35 & 15 & 50 \\
\hline & & \% within AgeGp & $70.0 \%$ & $30.0 \%$ & $100.0 \%$ \\
\hline
\end{tabular}

$\mathrm{X} 2=0.68, \mathrm{P}=0.711$ 


\section{Discussion :}

The rheumatoid arthritis is common autoimmune disease that more affected women than men in ratio $3: 1(17,18)$, the results of present study showed that nearly three quarter of the 50 Iraqi patients with RA who were treated with infliximab $(3 \mathrm{mg} / \mathrm{kg})$ every 8 weeks developed antibodies to infliximab (IgG antibodies)within 3 months of treatment.Furthermore,development of these antibodies was related to decreased in response to infliximab treatment. Up to the best of our knowledge, this is the first study investigating of antibodies to infliximab in Iraqi patients with RA on infliximab infusion treatment who suffering from persistant active disease. In this study, we observed an increased in frequency of anti-infliximab anti-bodies in Iraqi patients with $\mathrm{RA}(\mathrm{P}=0.000001)$ which is highly significant and not detected in controls and majority of these anti-bodies were reported more in females patients than males since the disease in more common in female than male (3:1)(), this finding agreed with previous studies done by Gerrit and Marijin(19).There are no relation of anti-infliximab anti-bodies development with patients age group $(\mathrm{P}=0.711)$. Indeed ,patients with detectable anti-infliximab antibodies in their serum show lower respose to infliximab compared with patients without anti-infliximab anti-bodies. This indicates that formation of anti-bodies to infliximab induces the clearance of infliximab from circulation.

Interestingly, we noted that in some patients who developed antiinfliximab antibodies that result in weak response to treatment, continuation of infliximab treatment with higher doses result in improvement in signs and symptoms of their diseases, This may be due to either infliximab cause induction of immune tolerance or overdosing the capacity of immune system to create these antibodies.

\section{Conclusion :}

Nearly three quarter of the Iraqi RA patients treated with infliximab developed anti-infliximab antibodies.

\section{Auther's contributions:}

Study conception: Muhammed M. Al-Ani

Study design: Nizar A. Jassim

Acquisition of data analysis: Mohammed A. Al-Karkhi

Interpretation of data: Batool M. Mahdi

Critical revision: Layth abd-alailah

References:

1. Firestein GS. Evolving concepts of rheumatoid arthritis. Nature 2003;423:356-61.

2. Kochi Y, Suzuki A, Yamada R, Yamamoto K. Genetics of rheumatoid arthritis: underlying evidence of ethnic differences. J Autoimmun 2009; 32(3-4):158-62.

3. McInnes IB, Schett G. Cytokines in the pathogenesis of rheumatoid arthritis. Nat Rev Immunol 2007;7:42942.

4. Smolen JS, Aletaha D, Koeller M, Weisman MH, Emery P.New therapies for treatment of rheumatoid arthritis. Lancet 2007;370:186174.

5. Mitoma H, Horiuchi T, Tsukamoto H, Tamimoto Y, Kimoto Y,Uchino A, et al. Mechanisms for cytotoxic effects of antitumor necrosis factor agents on transmembrane tumor necrosis factor alpha-expressing cells: comparison among infliximab, etanercept, and adalimumab. Arthritis Rheum. 2008;58:1248-57.

6. van Schouwenburg PA, Rispens T, Wolbink GJ. Immunogenicity of anti-TNF biologic therapies for rheumatoid arthritis. Nat Rev Rheumatol 2013;9:164-72.

7. Bolge SC, Carter CT, Mueller CS, Bailey RA, Ingham MP. Comparative multidatabase analysis of dosing patterns and infusion intervals for the first 12 infliximab infusions in patients with rheumatoid arthritis. Clin Ther 2012;34:2286-92.

8. Pascual-Salcedo D, Plasencia C, Ramiro S, Nuno L, Bonilla G, Nagore D, Del Ruiz AA, Martinez A, Aarden L, MartinMola E, et al: Influence of immunogenicity on the efficacy of long-term treatment with infliximab in rheumatoid arthritis. Rheumatology (Oxford) 2011, 50:1445-1452. (IVSL)

9. Inman RD, Maksymowych WP. A double-blind, placebocontrolled trial of low dose infliximab in ankylosing spondylitis. J Rheumatol 2010;37:120310.

10. Baranauskaite A, Raffayova H, Kungurov NV et al. Infliximab plus methotrexate is superior to methotrexate alone in the treatment of psoriatic arthritis in methotrexate-naive patients: the RESPOND study. Ann Rheum Dis 2012;71:5418.

11. Colombel JF, Sandborn WJ, Reinisch W et al. Infliximab, azathioprine, or combination therapy for Crohn's disease. $N$ Engl J Med 2010;362:138395.

12. Ducourau E, Mulleman D, Paintaud G, Chu Miow LD, Lauferon F, Ternant D, Watier H, Goupille P: Antibodies toward infliximab are associated with low infliximab concentration at treatment initiation and poor infliximab maintenance in rheumatic diseases. Arthritis Res Ther 2011, 13:R105.(IVSL)

13. Mulleman D, Meric JC, Paintaud G, Ducourau E, MagdelaineBeuzelin C, Valat JP, Goupille P: Infliximab concentration monitoring improves the control of disease activity in rheumatoid arthritis. Arthritis Res Ther 2009, 11:R178.

14. van den Bemt BJ, den Broeder AA, Wolbink GJ, Hekster YA, van Riel PL,Benraad B, van den Hoogen FH: Anti-infliximab antibodies are already detectable in most patients with rheumatoid arthritis halfway through an infusioncycle: an open-label pharmacokinetic cohort study. BMC Musculoskelet Disord 2011, 12:12.

15. Neogi T, Aletaha D, Silman AJ, Naden RL, Felson DT, Aggarwal R, et al. The American College of Rheumatology/ European League Against Rheumatism Classification Criteria for Rheumatoid Arthritis: Phase 2 methodological report. Arthritis Rheum 2010;62:2582-91.

16. Aletaha D, Neogi T, Silman AJ, et al.2010 Rheumatoid arthritis classification criteria: an American College of Rheumatology/ European League Against Rheumatism collaborative initiative. Ann Rheum Dis 2010;69:1580-8.

17. AL-Rawi ZS, AL-Azawi AJ, AL-Ajili FM, et al. Rheumatoid arthritis in population samples in Iraq. Ann Rheum Dis 1978; 37(1):73-5.

18. KhitamYasir Husain. Diagnostic value of anti-filaggrin antibodies in comparison with rheumatoid factors in Iraqi patients with rheumatoid arthritis. A thesis submitted to the scientific council of pathology in partial fulfilment of the requirements for the degree of fellowship of the Iraqi Board for medical specializations in pathology /Microbiology and immunology, 2011.

19. Gerrit Jan Wolbink, Marijn Vis, Willem Lems et al., Development of Antiinfliximab Antibodies and Relationship to Clinical Response in Patients With Rheumatoid Arthritis, American College of Rheumatology 2006, 711-715. 